$\begin{array}{ll} & \text { Etnográfica } \\ \text { etnográfica } & \text { Revista do Centro em Rede de Investigação em }\end{array}$

Antropologia

vol. $14(3) \mid 2010$

Vol. 14 (3)

\title{
Carlos Teixeira e Victor da Rosa (orgs.), The Portuguese in Canada: Diasporic Challenges and Adjustment
}

Sónia Ferreira

\section{OpenEdition}

Journals

\section{Edição electrónica}

URL: https://journals.openedition.org/etnografica/231

DOI: 10.4000/etnografica.231

ISSN: 2182-2891

\section{Editora}

Centro em Rede de Investigação em Antropologia

Edição impressa

Data de publição: 1 outubro 2010

Paginação: 617-630

ISSN: 0873-6561

\section{Refêrencia eletrónica}

Sónia Ferreira, «Carlos Teixeira e Victor da Rosa (orgs.), The Portuguese in Canada: Diasporic Challenges and Adjustment», Etnográfica [Online], vol. 14 (3) | 2010, posto online no dia 01 outubro 2010, consultado o 12 fevereiro 2022. URL: http://journals.openedition.org/etnografica/231 ; DOI: https:// doi.org/10.4000/etnografica.231

Este documento foi criado de forma automática no dia 12 fevereiro 2022.

\section{(c) (1) \&}

Etnográfica is licensed under a Creative Commons Attribution-NonCommercial 4.0 International License. 


\title{
Carlos Teixeira e Victor da Rosa (orgs.), The Portuguese in Canada: Diasporic Challenges and Adjustment
}

\author{
Sónia Ferreira
}

\section{REFERÊNCIA}

Carlos Teixeira e Victor da Rosa (orgs.), The Portuguese in Canada: Diasporic Challenges and Adjustment, Toronto/Buffalo/Londres, University of Toronto Press, 272 páginas. 2009

1 Na segunda edição da obra colectiva The Portuguese in Canada: Diasporic Challenges and Adjustment, originalmente publicada em 2000, os editores procuram conferir um novo fôlego à colectânea, substituindo e actualizando parte das contribuições, mas conservando os temas essenciais que a estruturam.

2 Os artigos cobrem um espectro disciplinar diversificado, desde a antropologia, à sociologia, história, geografia e literatura, e são produzidos por autores de instituições académicas canadianas e portuguesas, embora os primeiros sejam substancialmente mais representativos, já que uma parte essencial dos artigos aqui publicados foi apresentada, em 1997, no encontro anual da Canadian Association of Geographers. Segundo os editores, esta obra procura analisar e compreender um segmento importante da diáspora nacional, nomeadamente os portugueses que elegeram o Canadá como destino migratório. Este fluxo inicia-se de forma mais expressiva a partir dos anos 50, com a chegada do primeiro grupo de emigrantes ao porto de Halifax, a 13 de Maio de 1953, a bordo do navio Saturnia, e prolongar-se-á pelas décadas de 60, 70 e 80 , começando a diminuir apenas a partir dos anos 90 .

3 Os diferentes artigos, à excepção dos dois primeiros, encontram-se agrupados em quatro secções temáticas, intituladas respectivamente "Newfoundland and the White Fleet", "Immigration from Portugal to Canada", "Portuguese communities and 'Little Portugals"' e "History, cultural retention, and literature", perfazendo um total de 15 
contribuições. As duas primeiras procuram oferecer uma análise conjuntural sobre os processos migratórios portugueses, a começar com um artigo dos editores Carlos Teixeira e Victor da Rosa, onde estes apresentam os fluxos de chegada e fixação das populações portuguesas em território canadiano. $\mathrm{O}$ segundo artigo, da autoria de Maria Beatriz Rocha-Trindade, foca de forma abrangente os processos migratórios portugueses, procurando situá-los nas suas dinâmicas históricas próprias, da época da expansão ultramarina aos mais recentes fenómenos das migrações transoceânicas para a América do Sul e do Norte, à migração intra-europeia e aos processos de migração de retorno, finalizando com uma breve caracterização da diáspora portuguesa.

4 A organização da obra procura assim cobrir um espectro diacrónico que vai, com excepção do artigo de Maria Beatriz Rocha-Trindade, do séc. XIX à contemporaneidade multicultural de metrópoles como Toronto, Vancouver ou Montreal, sendo que, em termos de escala, são analisados dados produzidos tanto a nível macro como micro, variando as fontes entre documentos históricos, imprensa, testemunhos orais e inquéritos.

5 A primeira secção temática foca-se na migração de carácter económico e sazonal que caracterizava a chegada maciça de portugueses às costas canadianas para a pesca do bacalhau, actividade que começa a surgir de forma organizada a partir de 1830, aproximadamente, e que não cessará nas décadas subsequentes. Priscilla Doyle não só explora as questões históricas e os aspectos tecnológicos inerentes a esta actividade, como analisa todo o projecto iconográfico promovido pelo Estado Novo para controlar ideologicamente as representações nacionais que visavam este tema. Jean-Pierre Andrieux e Peter Collins discutem igualmente a questão da pesca, nomeadamente evocando a famosa frota White Fleet, procurando compreender, por um lado, as estratégias que os pescadores utilizavam com vista à renovação das embarcações e, por outro, a memória local deixada pelos portugueses nesta região costeira do Canadá. Collins destaca a ausência de documentação e fontes que atestem este fluxo tão intenso de indivíduos, principalmente entre as décadas de 40 e 70 do séc. $\mathrm{XX}$, procurando o autor registos memoriais, de imprensa e performativos da região de Newfoundland.

6 A segunda secção centra-se em aspectos mais ligados às questões da cidadania, evocando movimentos sociais ou acções colectivas levadas a cabo pela comunidade portuguesa no Canadá. Em primeiro lugar, Manuel Armando Oliveira analisa a questão da designada retenção cultural, ou seja, processos de preservação da língua e da cultura portuguesa tanto em Montreal como em Toronto, particularmente junto da comunidade açoriana. Seguidamente, Susana Miranda investiga uma acção de resistência e luta colectiva levada a cabo por mulheres portuguesas migrantes, trabalhadoras do sector económico das limpezas em Toronto. A autora analisa a configuração política das suas acções e a sua constituição em "militantes étnicas", procurando desconstruir o estereótipo da "mulher da limpeza portuguesa", redefinindo conceitos como o de público ou de político e os papéis de género adjacentes. Ainda no âmbito desta secção, Luís Aguiar descreve o caso da deportação de Hélder Marques, analisando os diferentes discursos emanados a partir da comunidade portuguesa e da sociedade canadiana. $\mathrm{O}$ autor analisa a forma como se organizou a resistência à deportação e os discursos que a enformaram, destacando aspectos como a importância do argumento étnico e o modo como esta situação revela alguns dos problemas da comunidade luso-canadiana, tornando visível o seu estatuto e posicionamento ainda marginal. Irene Bloemraad discute, por fim, a questão da invisibilidade das 
comunidades portuguesas nos EUA e no Canadá, defendendo, ao contrário de outros autores, que não existem semelhanças estruturais entre ambas. Bloemraad considera que no Canadá se verifica um maior envolvimento político e cívico da comunidade portuguesa, devendo-se essa situação a vários factores, entre eles as políticas multiculturais implementadas naquele país.

7 Na terceira parte da obra, Carlos Teixeira e Robert Murdie apresentam os padrões de ocupação do território, a mobilidade residencial e a escolha do tipo de habitação mais visíveis na comunidade portuguesa de Toronto. Os autores analisam ainda o fenómeno da suburbanização e a configuração sociodemográfica que distingue a zona portuguesa do centro de Toronto da do subúrbio de Mississauga. Victor da Rosa e Carlos Teixeira analisam ainda, no artigo subsequente, a presença portuguesa na Província do Quebeque, apresentando as características sociais desta comunidade - ocupação e educação, tipos e locais de residência, vida comunitária - assim como o processo de suburbanização para a zona do Laval. Conclui esta secção um artigo de Carlos Teixeira sobre a fixação dos portugueses em zonas rurais do Canadá, como Okanagan Valley. 0 autor analisa as actividades empresariais agrícolas e as experiências de gestão financeira dos emigrantes portugueses desta região, destacando o facto de a sua estratégia de fixação residencial ser diferente da verificada em urbes como Toronto ou Montreal, embora a posse da terra assuma igualmente um sentido económico e simbólico fundamental.

8 Na quarta e última parte da obra, temos um ensaio de Onésimo Teotónio Pereira onde este discute as características culturais de um grupo nacional como o português, ancorando-se em autores como Jorge Dias e Leite de Vasconcelos. 0 autor defende que as comunidades portuguesas que vivem fora do país apresentam uma grande coerência e unificação cultural e explora ensaisticamente esta proposição. No capítulo que se segue, Isabel Patim analisa a "literatura portuguesa de background canadiano", destacando o processo tardio da sua inclusão na definição de obra literária e de que forma isso acompanha a própria enunciação e delimitação do conceito de literatura canadiana. Por fim, um artigo da autoria de John Warkentin finaliza a obra, apresentando uma síntese final dos artigos que a constituem e analisando-os no seu conjunto.

9 A presente colectânea pretende fazer assim uma apresentação sumária, interdisciplinar e diacrónica do fenómeno da emigração portuguesa para o Canadá. A diversidade dos pontos de vista apresentados, a exaustividade geográfica e a tentativa de conferir espessura histórica ao tema constituem factores relevantes para uma apreciação positiva da mesma. É de notar, contudo, a ausência de temáticas que reflictam, por exemplo, as estratégias familiares e matrimoniais, os processos heterogéneos de reconfiguração identitária da segunda e terceira gerações ou o papel da cultura material e performativa na definição e circunscrição da ideia de "comunidade". Estas ausências, tanto quanto as presenças, que constituem um contributo de relevo, deverão no seu todo ser objecto de reflexão. Quem produz o quê, quando e como sobre a diáspora portuguesa? Que produção científica a enforma? Quais os agentes que tendencialmente a produzem? 


\section{AUTORES}

SÓNIA FERREIRA

CRIA/FCSH-UNL 